\title{
PEMBUATAN TAMAN BACAAN SEBAGAI UPAYA PENINGKATAN MINAT LITERASI ANAK-ANAK DAN REMAJA KAMPUNG CISARONI- DESA CIKAHURIPAN LEMBANG
}

\author{
Purwinda Iriani, Yanti Suprianti, Susilawati, Annisa Syafitri K. \\ Jurusan Teknik Konversi Energi, Politeknik Negeri Bandung \\ Jl. Gegerkalong Hilir, Desa Ciwaruga, Ciwaruga, Parongpong, Kabupaten Bandung Barat, Jawa \\ Barat 40012, Indonesia \\ Email: purwinda.iriani@polban.ac.id, yantisuprianti.ys@gmail.com, susilawati@polban.ac.id, \\ annisa.syafitrik@polban.ac.id
}

\begin{abstract}
ABSTRAK
Keberadaan tempat bacaan seperti perpustakaan, taman bacaan, dan ruang serupa, mampu menumbuhkan minat seseorang dalam membaca buku, serta memberi manfaat pada bertambahnya interaksi sosial bagi yang memiliki minat baca, dan secara tidak langsung kegiatan ini mengarah ke arah yang lebih positif. Pengabdian masyarakat kali ini akan dilakukan di Kampung Cisaroni, Desa Cikahuripan, RT 05 RW 08. Berdasarkan pengamatan saat kunjungan ke lapangan, terdapat potensi untuk dikembangkannya taman bacaan atau perpustakaan. Di daerah tersebut terdapat banyak anak-anak usia sekolah yang memiliki cukup banyak waktu senggang dan selama ini baru diisi dengan kegiatan bersekolah dan mengaji saja. Wilayah desa yang termasuk daerah sub-urban memiliki kesulitan akses transportasi, sehingga menyebakan warga semakin sulit untuk menjangkau berbagai sarana informasi, khususnya taman bacaan atau perpustakaan yang mumpuni. Melalui pengabdian kepada masyarakat ini tim P2M JTKE membuat perpustakaan yang dinamai taman Bacaan Sadulur untuk meningkatkan minat baca masyarakat, terutama anak-anak. Taman bacaan ini mendapatkan antusiasme yang tinggi dari masyarakat, ditandai dengan banyaknya anak-anak yang hadir dan masyarakat yang membantu pada saat persiapan, sosialisasi dan peresmian taman bacaan ini. Diharapkan dengan adanya taman bacaan ini dapat meningkatkan pengetahuan masyarakat di Kp. Cisaroni, sehingga dapat mengembangkan wawasan dan meningkatkan kemandiriannya di masa yang akan datang.
\end{abstract}

Kata kunci : taman bacaan, literasi, pengabdian masyarakat, buku bacaan

\section{PENDAHULUAN}

Tingkat budaya membaca pada suatu masyarakat dapat diukur melalui tiga indikator (Saepudin, 2015). Indikator yang pertama, yaitu dapat dilihat dari ketersediaan fasilitas, khususnya seperti perpustakaan (sekolah atau umum, dan perpustakan desa atau sudut buku). Indikator kedua dapat dilihat dari rata-rata penggunaan sumber bacaan yang dimiliki oleh suatu perpustakaan (baik dari jumlah dan jenis buku) seperti, kunjungan masyarakat ke perpustakan, tingkat penggunaan koleksi serta keanggotaan perpustakaan. Indikator terakhir untuk melihat kebiasaan membaca masyarakat dapat diukur dari rata-rata durasi membaca (per-kali membaca), rata-rata frekuensi membaca selama satu minggu dan tujuan dari membaca itu sendiri. 
Warga desa Cisaroni yang bermukim di wilayah RT 05 RW 08 Kampung Cisaroni, Desa Cikahuripan, Kabupaten Lembang. Pada tahun 2016, tim pengabdian kepada masyarakat dari Jurusan Teknik Konversi Energi (JTKE) telah sukses melaksanakan program diseminasi teknologi di salah satu unit peternakan sapi Kampung CisaroniDesa Cikahuripan melalui kelompok Tani Ternak Sukatinggi 1. Bentuk penerapan teknologi hasil pengembangan dosen Teknik Konversi Energi adalah berupa konversi limbah ternak sapi menjadi biogas melalui pemasangan 1 unit digester kapasitas $3 \mathrm{~m}^{3}$ (Iriani dkk., 2016). Pada lokasi tersebut terdapat 58 kepala keluarga yang pada umumnya berprofesi sebagai petani sayuran, peternak dan pemerah sapi, serta pencari alang-alang sebagai pakan ternak. Jumlah anak-anak dan remaja usia 4-15 tahun ada berjumlah 68 orang. Jarak antara lokasi tempat tinggal dan sekolah ditempuh melalui jarak $3 \mathrm{~km}$ untuk Sekolah Dasar dan 5 km untuk Sekolah Menengah Pertama dan Sekolah Menengah Atas, dengan rute dan profil jalan yang berbeda-beda.

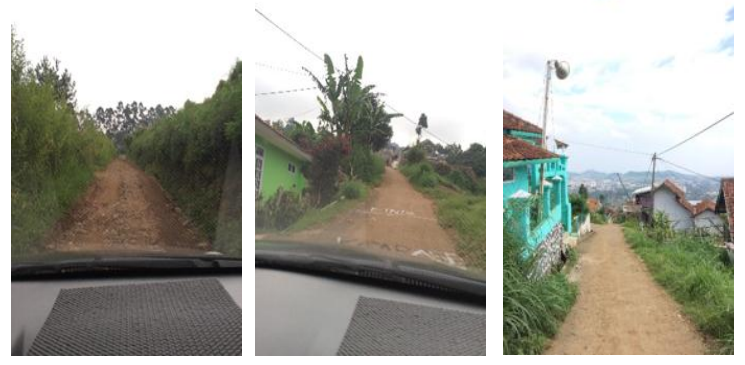

Gambar 1. Lokasi Mitra - Kampung Cisaroni- Desa Cikahuripan

Di lokasi tersebut, tidak terdapat angkutan umum atau kendaraan roda empat yang mengantarkan anak-anak tersebut, sehingga pada umumnya mereka pergi ke sekolah dengan berjalan kaki. Profil jalan dan tempat menuju sekolah dari lokasi pemukiman warga dapat dilihat pada Gambar 1 .
Pada kunjungan awal ke tempat koordinator Kelompok Tani Ternak Sapi Sukatinggi 1, diketahui terdapat beberapa permasalahan umum yang menjadi kendala sehari-hari kegiatan warga setempat. Informasi tersebut diperoleh melalui wawancara dan peninjauan langsung ke beberapa lokasi pemeliharaan sapi perah. Di antara permasalahan umum yang ditemui adalah sebagai berikut:

a. Kegiatan anak-anak dan remaja kampung Cisaroni diluar jam sekolah lebih kepada membantu orang tua, mengaji, dan bermain (Gambar 2).

b. Tidak semua anak-anak dari kampung Cisaroni yang telah lulus dari Sekolah Dasar kemudian melanjutkan ke tingkatan SMP dan SMA. Kurang lebih setengah dari populasi anak-anak tersebut hanya sampai pada lulusan SD. Kegiatan dari mereka mayoritas membantu orang tua bekerja di kebun atau kandang ternak.

c. Bentuk perhatian orang tua dalam pemberian pendidikan anak lebih menggantungkan kepada kegiatan formal seperti sekolah. Kegiatan non formal yang berlangsung di sekitaran desa hanya kegiatan mengaji yang dilakukan rutin setiap hari di mushalla mesjid.

d. Kegiatan mengaji pada anakanak dan remaja di sekitar area tersebut, sangat bergantung pada kehadiran guru/ustadz. Pada kondisi tertentu, terdapat kesulitan dalam mencari guru/ustadz yang mau mengajar, karena rute menuju lokasi yang sulit terjangkau dan jarak dari pusat kota yang cukup jauh, serta ketersediaan insentif yang kurang dalam mengkompensasi kegiatan tersebut.

e. Keterbatasan SDM dalam pengelolaan peternakan sapi. Pekerja yang mengurus sapi tidak tetap, karena 
upahnya dianggap kurang mencukupi untuk memenuhi kebutuhan hidup. Warga lebih memilih menjadi buruh bangunan di luar lokasi desa.

f. Warga yang mayoritas adalah petani sayur dan peternak sapi (jasa perawatan sapi) memiliki keterbatasan pendapatan yang diperoleh dari upah harian, mingguan, dan atau bulanan. Adapun dokumentasi dari beberapa kegiatan dari anak-anak dan remaja Kampung Cisaroni dapat dilihat pada Gambar 2 berikut.

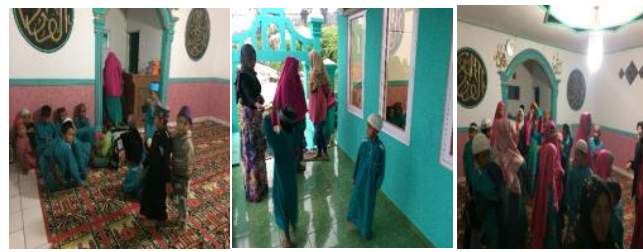

Gambar 2. Kegiatan anak-anak dan remaja kampung Cisaroni di sekitar mesjid

Adapun dari hasil pengamatan tersebut didapatkan pula beberapa permasalahan yang spesifik, yaitu terkait dengan ketersediaan sarana dan prasarana penunjang sarana baca. Terdapat tiga hal utama yang diperhatikan, yaitu :

1. Tempat pendidikan non formal

Hingga saat ini baru terdapat hanya satu tempat pendidikan non formal yang didirikan di Kampung Cisaroni, yaitu berupa sebuah mushalla yang saat ini digunakan untuk aktivitas pengajian setiap sore hari, baik oleh warga, khususnya ibu-ibu, dan juga anak-anak. Kondisi fisik dari mushalla terbilang sederhana dengan fasilitas area shalat sekitar 5 × 5 meter, fasilitas tempat wudhu terbatas untuk dua orang dan sebuah kamar mandi berukuran $1,5 \times 1$ meter. Waktu penggunaan dari mushalla ini juga tertentu dikarenakan terbatasnya sumber daya manusia yang dapat mengelola keberlangsungan berbagai aktivitas penunjang kegiatan non formal di mushalla tersebut. Selain itu juga tidak terdapat sumber dana yang tetap untuk menunjang berbagai kegiatan operasional yang diperlukan.

\section{Sarana infrastruktur}

Akses jalan antar rumah penduduk dan antar kampung dengan area urban belum optimal sehingga akses hiburan atau tempat rekreasi-edukasi terbatas (Gambar 3).

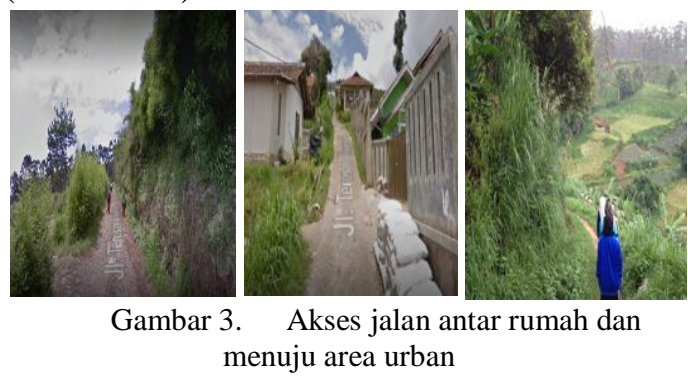

3. Sarana yang belum termanfaatkan

Terdapat kandidat tempat untuk taman bacaan atas kesediaan warga untuk dijadikan taman bacaan di sekitar area tersebut yang lokasinya berada di samping mushalla (Gambar 4 dan Gambar 5).
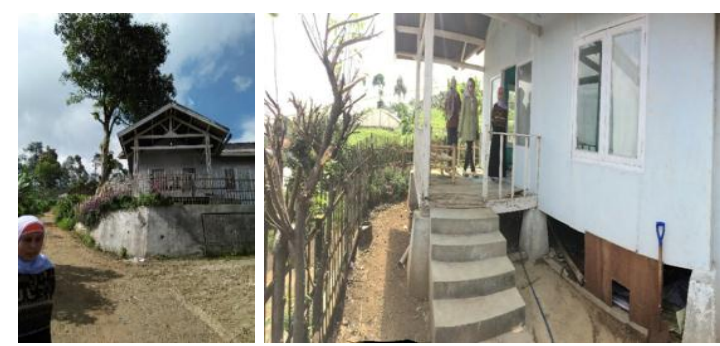

Gambar 4. Kandidat tempat yang potensial dijadikan taman bacaan (bagian luar depan)

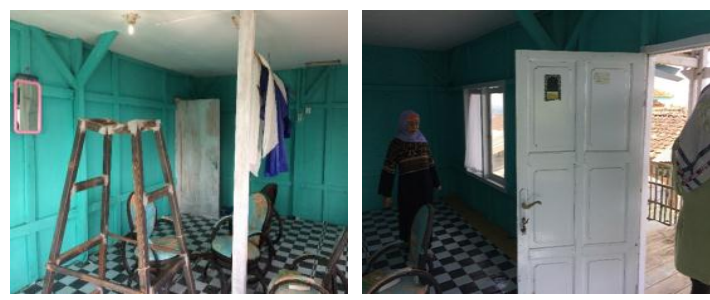

Gambar 5. Kandidat tempat yang potensial dijadikan taman bacaan (bagian dalam)

Menurut pemilik rumah tersebut, okupasi rumah tersebut belum maksimal dan hanya digunakan untuk keperluan 
kegiatan insidental, akibatnya rumah kurang terawat.

\section{METODE}

Dari berbagai permasalahan diatas yang bermuara pada belum tersedianya sarana dan prasarana penunjang peningkatan minat membaca warga masyarakat Kampung Cisaroni, khususnya bagi anak usia sekolah, maka dapat dijustifikasi penentuan persoalan beserta solusinya pada Tabel 1 . berikut.

Tabel 1. Justifikasi Penentuan Persoalan Peningkatan Minat Baca di Kpg. Cisaroni

\begin{tabular}{|c|c|c|}
\hline Faktor & Permasalahan & $\begin{array}{l}\text { Solusi yang } \\
\text { Ditawarkan }\end{array}$ \\
\hline $\begin{array}{l}\text { Infra- } \\
\text { Struktur } \\
\text { Desa }\end{array}$ & $\begin{array}{l}\text { Belum terdapat } \\
\text { ruang khusus } \\
\text { tempat } \\
\text { penyimpanan } \\
\text { informasi } \\
\text { khususnya karya } \\
\text { cetak yang dapat } \\
\text { diakses untuk } \\
\text { pengembangan } \\
\text { kapasitas anak- } \\
\text { anak dan remaja } \\
\text { usia sekolah yang } \\
\text { bersifat non } \\
\text { formal. }\end{array}$ & $\begin{array}{l}\text { Kerjasama } \\
\text { dengan sipil } \\
\text { (warga) terkait } \\
\text { ketersediaan } \\
\text { penggunaan } \\
\text { tempat bagi } \\
\text { aktivitas positif } \\
\text { untuk anak-anak } \\
\text { dan remaja, } \\
\text { melalui } \\
\text { pembentukan } \\
\text { taman bacaan. }\end{array}$ \\
\hline $\begin{array}{l}\text { Perangkat } \\
\text { Desa }\end{array}$ & $\begin{array}{l}\text { Belum terdapat } \\
\text { program khusus } \\
\text { dari } \\
\text { kecamatan/kelura } \\
\text { han dan RT/RW } \\
\text { yang } \\
\text { memfokuskan } \\
\text { pada peningkatan } \\
\text { minat baca anak- } \\
\text { anak dan remaja } \\
\text { di Kampung } \\
\text { Cisaroni- Desa } \\
\text { Cikahuripan. }\end{array}$ & $\begin{array}{l}\text { Pengenalan } \\
\text { program } \\
\text { peningkatan } \\
\text { minat baca anak } \\
\text { melalui taman } \\
\text { bacaan, yang } \\
\text { diharapkan akan } \\
\text { membuka } \\
\text { peluang } \\
\text { keterlibatan } \\
\text { instansi } \\
\text { pemerintah } \\
\text { ataupun non- } \\
\text { pemerintah dalam } \\
\text { pengembanganny } \\
\text { a di masa depan. }\end{array}$ \\
\hline $\begin{array}{l}\text { Latar } \\
\text { belakang } \\
\text { Pendidikan } \\
\text { dan } \\
\text { pekerjaan } \\
\text { Warga }\end{array}$ & $\begin{array}{l}\text { 1. Rata-rata } \\
\text { tingkat } \\
\text { pendidikan } \\
\text { warga adalah } \\
\text { lulusan SMP } \\
\text { dan sebagian }\end{array}$ & \begin{tabular}{l}
\multicolumn{2}{c}{ Pembukaan } \\
wawasan anak \\
dan remaja \\
melalui buku dan \\
berbagai sarana \\
dan prasarana
\end{tabular} \\
\hline
\end{tabular}

\begin{tabular}{|c|c|c|}
\hline & \begin{tabular}{lr}
\multicolumn{2}{r}{ adalah lulusan } \\
SMA. \\
2. & Pekerjaan \\
warga & selama ini \\
masih & sangat \\
terbatas & pada \\
bidang pertanian \\
dan peternakan \\
dengan lingkup \\
terbatas.
\end{tabular} & $\begin{array}{l}\text { taman bacaan, } \\
\text { sehingga dapat } \\
\text { memberikan } \\
\text { gambaran profesi } \\
\text { lain yang dapat } \\
\text { dicapai kelak, } \\
\text { selain bidang } \\
\text { pertanian dan } \\
\text { peternakan. Juga } \\
\text { dapat ditambah } \\
\text { buku penunjang } \\
\text { peningkatan } \\
\text { kapasitas warga } \\
\text { terkait bidang } \\
\text { pertanian yang } \\
\text { lebih mutakhir } \\
\text { untuk menambah } \\
\text { wawasan dalam } \\
\text { peningkatan } \\
\text { ekonomi lokal. }\end{array}$ \\
\hline $\begin{array}{l}\text { Pendidikan } \\
\text { terakhir } \\
\text { anak dan } \\
\text { remaja } \\
\text { desa }\end{array}$ & $\begin{array}{l}\text { Pada umumnya } \\
\text { pendidikan } \\
\text { terakhir yang } \\
\text { diembann oleh } \\
\text { anak-anak di desa } \\
\text { tersebut adalah } \\
\text { sebagai lulusan } \\
\text { Sekolah Dasar. } \\
\text { Beberapa } \\
\text { melanjutkan ke } \\
\text { jenjang SMP dan } \\
\text { hanya segelintir } \\
\text { yang mampu } \\
\text { melanjutkan ke } \\
\text { tingkat SMA. } \\
\text { Faktor } \\
\text { ketidaberlanjutan } \\
\text { jenjang } \\
\text { pendidikan lebih } \\
\text { didominasi karena } \\
\text { alasan ekonomi } \\
\text { orang tua yang } \\
\text { kurang } \\
\text { menunjang. }\end{array}$ & $\begin{array}{l}\text { Untuk tetap } \\
\text { menjaga } \\
\text { keberlangsungan } \\
\text { pengetahuan } \\
\text { yang telah } \\
\text { diperoleh dari } \\
\text { jenjang } \\
\text { pendidikan } \\
\text { sebelumnya, } \\
\text { ditawarkan } \\
\text { penyediaan } \\
\text { taman bacaan } \\
\text { untuk terus } \\
\text { mengeksplorasik } \\
\text { an informasi } \\
\text { terbaru. }\end{array}$ \\
\hline
\end{tabular}

Metode pelaksanaan yang dilakukan pada pengabdian kepada masyarakat di lingkungan warga RT 05 RW 08 Desa Cisaroni Kabupaten Lembang ini akan didasarkan dari hasil analisis situasi yang dijumpai dan disepakati oleh Mitra sebagai bentuk solusi yang ditawarkan. Adapun detail tahapan yang dilaksanakan adalah sebagai berikut : 


\section{Tahap I}

a. Survey. Pada tahap ini tim pengabdian masyarakat melakukan visitasi lapangan ke tempat mitra, yakni ke Kampung Cisaroni, Desa Cikahuripan, tempat Kelompok Tani Ternak Sapi Sukatinggi 1 berlokasi. Metode yang digunakan dalam tahap ini adalah wawancara dan pengambilan dokumentasi di lokasi. Wawancara dilakukan langsung dengan ketua kompok Tani Ternak Sukatinggi 1. Dari hasil analisis yang diperoleh, maka dirumuskan dan dipilih masalah yang telah dijustifikasi oleh mitra.

\section{b. Koordinasi dengan mitra.} Pada tahap ini hasil justifikasi permasalahan telah disepakati oleh mitra dan perumusan serta penentuan tujuan kegiatan pengabdian dapat dibuat. Dari hal tersebut muncul garis besar solusi yang ditawarkan oleh tim P2M Jurusan Teknik Konversi Energi (JTKE) seperti workshop / sosialisasi, penerapan, monitoring, dan lain-lain. Bentuk-bentuk solusi yang ditawarkan tersebut, tentunya memerlukan koordinasi dengan mitra agar tujuan kegiatan P2M tercapai.

c. Studi Literatur. Tim P2M JTKE melakukan penelusuran referensi yang berkaitan dengan pengembangan taman bacaan di area tersebut, agar anak-anak dan remaja sekitar area tersebut dapat menggunakan, menikmati dan merasakan manfaatnya.

\section{Tahap II}

a. Penyiapan ruang taman bacaan. dalam hal ini tim P2M JTKE dan mitra saling berkoordinasi mengenai ketersediaan tempat yang dapat digunakan sebagai taman bacaan. Pada proses penyiapannya akan dilakukan perbaikan dan perawatan bagian-bagian dari ruangan tersebut yang nantinya mendukung aktivitas membaca, seperti memeriksa kebocoran, penambalan dan perbaikan bagian yang retak, pengecetan ruangan, dan bentuk penyiapan lainnya yang pelaksanaannya membutuhkan jasa dari luar (tukang bangunan).

b. Penyiapan buku bacaan. Jenis buku yang akan disumbangkan untuk taman bacaan akan bervariasi dan tentunya disesuikan berdasarkan kebutuhan dari warga mengikuti usia pembaca. Berdasarkan hasil penelitian Rahayu dkk. (2016) menyebutkan bahwa studi yang dilakukan pada siswa SD lebih memilik jenis buku cerita da bahan bacaan fiksi untuk dijadikan bahan bacaan. Apabila memperhatikan dari percakapan dengan warga saat survey awal, warga juga cukup membutuhkan suplai referensi bukubuku religius mengingat tidak mudahnya akses untuk mendapatkan pengetahuan terkait dari praktisi agama karena berbagai hal yang salah satunya adalah keterbatasan anggaran.

\section{Tahap III}

a. Pembinaan dan sosialisasi. Tim pelaksana pengabdian masyarakat P2M JTKE akan mencoba membentuk tim kepengurusan yang terdiri dari warga masyarakat itu sendiri, dan memberikan pengenalan dan pengarahan dalam mengelola administrasi dan inventarisasi perpustakaan. Sosialisasi mengenai taman bacaan sebenarnya telah dilakukan sejak saat survei awal, dan sosialisasi lanjutan yang akan dilakukan lebih ke arah pengenalan masyarakat dengan sistem perpustakaan yang baru.

b. Monitoring. Proses pemantauan akan dilakukan secara berkala oleh tim pengabdian masyarakat P2M JTKE yang dapat dilakukan baik dengan langsung dilakukan kunjungan ke perpustakaan ataupun secara tidak 
langsung yaitu dengan memanfaatkan perangkat komunikasi yang ada saat ini. Proses ini ditujukan untuk memantau ketaatadministrasian pengelolaan perpustakaan baik dari warga dan terutama oleh tim kepengurusan yang telah dibentuk.

c. Evaluasi. pada akhir masa pelaksanaan program pengabdian masyrakat akan dilakukan evaluasi awal untuk melihat seberapa besar kemampuan dari masyarakat untuk menjaga keberlangsungan dari perpustakaan beserta sistemnya ini. Adapun evaluasi lanjutan dapat dilakukan untuk melakukan peningkatan baik dari segi sarana dan prasarana maupun segi pelayanannya apabila warga dianggap telah cukup mampu untuk menjaga keberlangsungan fasilitas yang mereka miliki. a. Rekomendasi. pada tahap ini tim P2M JTKE akan memberikan rekomendasi kepada mitra terkait upaya-upaya pengembangan perpustakaan terkait dengan berbagai bidang lain (contoh kewirausahaan) dengan memperkenalkannya kepada berbagai instansi lainnya yang mungkin tertarik untuk ikut serta dalam program pengembangan taman baca di Desa Cisaroni.

\section{b. Penyusunan laporan akhir.} Tim P2M JTKE menyusun dan melaporkan hasil kegiatan pengabdian masyarakat bersama mitra, ke UPPM Polban. Laporan kegiatan P2M tersebut juga akan diserahkan kepada mitra. Adapun gambaran utuh tahap per tahap dari pelaksanaan dapat dilihat pada Gambar 6 berikut.

\section{Tahap IV}

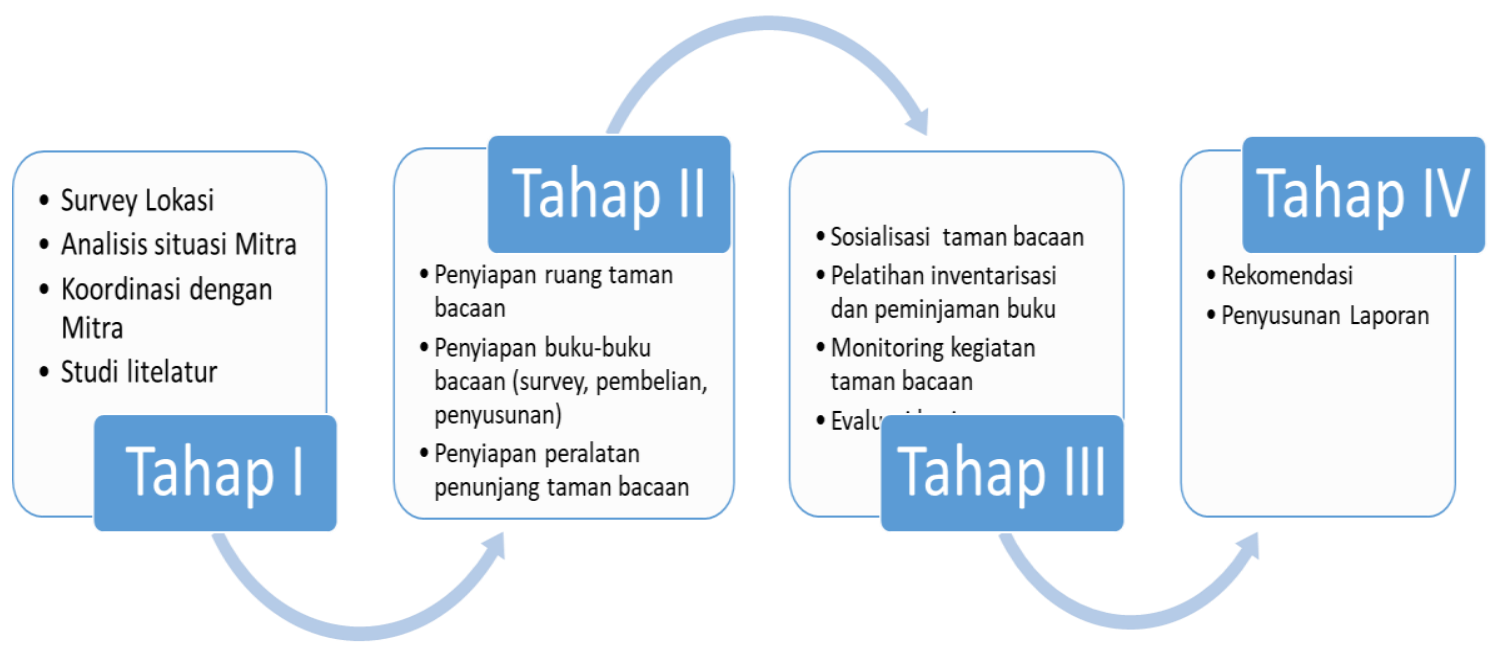

Gambar 6. Gambar Pengembangan Taman Bacaan di kampung Cisaroni- Desa Cikahuripan, Kabupaten Lembang 


\section{HASIL DAN PEMBAHASAN}

\section{Penyiapan Ruang Taman} Bacaan. Tim P2M JTKE dan mitra sudah berkoordinasi mengenai penyiapan tempat. Tempat yang akhirnya dipilih merupakan sebuah rumah panggung milik mitra yang belum didayagunakan dan sudah sejak awal direncanakan untuk digunakan sebagai tempat berkegiatan bagi masyarakat di Cisaroni. Adanya kegiatan pengabdian masyarakat ini, sekaligus menjadi titik awal pengaktifan kembali rumah tersebut.

Untuk menunjang kegiatan penyiapan taman bacaan, tim P2M JTKE bekerjasama dengan mitra melakukan pemeriksaan bangunan, seperti pemeriksaan kebocoran atap dan ketersediaan penerangan, kebersihan rumah, dan lain sebagainya, sehingga saat ini sudah dalam keadaan layak untuk digunakan beraktivitas (Gambar 7).

Kondisi interior dasar ruangan, seperti cat dinding ruangan masih layak dan belum perlu untuk dilakukan pengecatan ulang. Ketersediaan fasilitas penunjang kebersihan juga mendukung, dengan sudah tersedianya kamar kecil yang dapat digunakan oleh pengunjung taman bacaan nantinya.

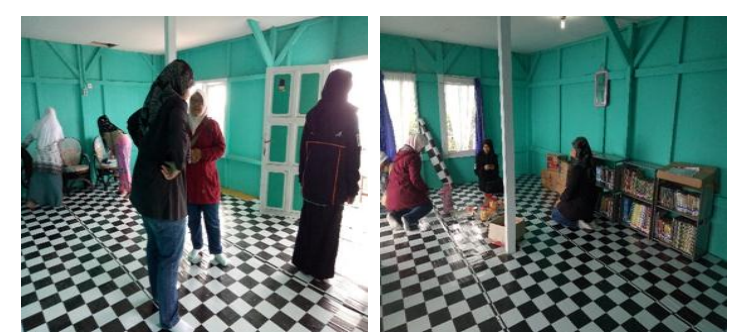

Gambar 7. Bagian dalam Perpustakaan saat Proses Penyiapan

\section{Pengadaan dan Inventarisasi Buku Bacaan serta Panduan}

\section{Pengelolaan}

Perpustakaan.

Pemenuhan buku-buku bacaan yang dibutuhkan pada kegiatan ini, dilakukan baik dengan cara pembelian langsung ke tempat penjualan buku, atau dengan pemesanan secara online via aplikasi penjualan buku. Jenis buku- buku yang dipilih sebagian besar merupakan buku untuk belajar membaca, buku ilmu pengetahuan umum dan buku cerita rakyat. Adapun sebagiannya lagi merupakan buku-buku religi untuk anak- anak, novel remaja, komik anak dan ensiklopedia (sejarah, ilmu pengetahuan dan teknologi). Pemilihan jenis buku ini diharapkan dapat memenuhi minat anak-anak dan remaja yang umumnya lebih menyukai jenis buku cerita dan bahan bacaan fiksi (Rahayu, et al., 2016).
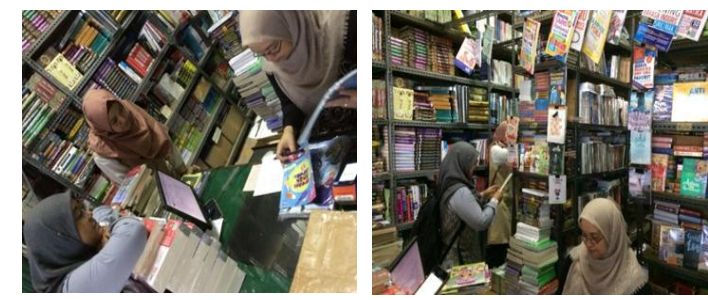

Gambar 8. Pencarian dan Pembelian BukuBuku Bacaan

Proses pembelian buku di tempat penjualan buku, dilakukan oleh tim P2M JTKE secara langsung seperti terlihat pada Gambar 8.

Setelah buku-buku bacaan terkumpul, maka dilakukan kegiatan inventarisasi yang dilakukan di Jurusan Teknik Konversi Energi. Kegiatan inventarisasi buku memerlukan total waktu empat minggu dengan rincian kegiatan, yaitu inventarisasi melalui identifikasi dan pendataan informasi buku, pengelompokan buku berdasarkan kategori dan klasifikasi Dewey Decimal Classification (DDC), kompilasi data inventarisasi ke dalam format Ms. 
Excel, pembuatan label untuk identitas buku, pengecapan, dan penyusunan buku per ketagori dalam rak.

Berdasarkan hasil inventarisasi, total buku yang diberikan yaitu sebanyak 411 buah buku. Buku - buku tersebut terdiri atas delapan jenis klasifikasi buku, yaitu karya umum (000), agama (200), ilmu-ilmu social (300), ilmu-ilmu alam dan matematika (500), teknologi dan ilmu-ilmu terapan (600), kesenian, hiburan dan olahraga (700), kesusastraan (800), dan kategori geografi dan sejarah (900). Dengan adanya inventarisasi ini, diharapkan akan memudahkan pencarian dan pengecekan buku oleh pengelola taman bacaan. Kegiatan tersebut dilakukan oleh tim P2M JTKE dan bantuan beberapa mahasiswa JTKE seperti pada Gambar 9.

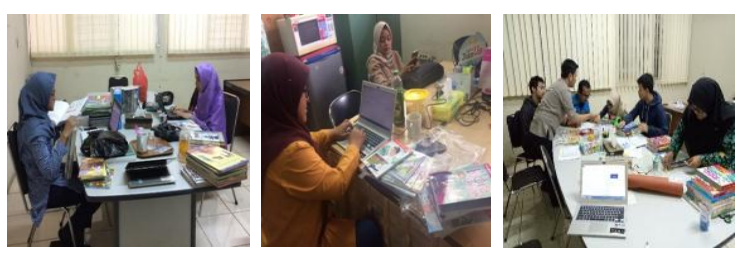

Gambar 9. Kegiatan Inventarisasi dan Pemberian Label Buku

Data hasil inventarisasi buku-buku awal yang telah dimasukkan ke dalam pendataan dapat dilihat pada lampiran. Pengisian daftar inventarisasi ini dilakukan secara berkelanjutan oleh pengelola bacaan, dengan format yang telah diberikan.

Selain penyiapan inventarisasi buku, taman bacaan di Cisaroni ini juga dilengkapi dengan buku panduan pengelolaan buku atau Standard Operating Prosedur (SOP) pelaksanaan perpustakaan yang telah dirangkumkan dari beberapa referensi, yaitu Manajemen Perpustakaan Sekolah
(Lasa, 2007), Panduan Penyelenggaraan Perpustakaan Sekolah (Sumantri, 2002), dan Pedoman Penyelenggaraan Perpustakaan Sekolah (Yusuf, et al., 2005). Perpustakaan juga dilengkapi dengan buku kunjungan taman bacaan yang akan berisi daftar pengunjung perpustakaan, dan cap Perpustakaan Sadulur yang diberikan pada saat peresmian perpustakaan (Gambar 10).

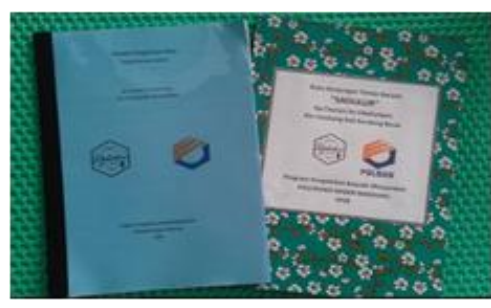

Gambar 10. Buku Panduan

Pengelolaan Buku dan Buku

Kunjungan Taman Bacaan Sadulur

\section{Penyiapan Penunjang \\ Peralatan}

Kenyamanan

pengunjung merupakan salah satu faktor yang perlu diperhatikan dalam menarik minat kunjungan taman bacaan ini. Diperlukan saran dan prasarana yang memadai, seperti penerangan dan tempat duduk dan fasilitas ruang baca lainnya, agar aktivitas membaca menjadi hal yang menyenangkan. Tim P2M JTKE berencana untuk memberikan penggantian penerangan ruangan, karena saat cuaca mendung, ternyata penerangan di tempat ini menjadi kurang nyaman untuk aktivitas membaca. Di bagian dalam telah tersedia beberapa kursi untuk pengunjung, namun belum memadai jika pengunjung datang dalam jumlah banyak. Untuk mengatasi hal ini, ditambahkan karpet-karpet agar anakanak lebih leluasa dan nyaman saat membaca. Tim P2M JTKE juga menyediakan rak-rak berdiri untuk 
menyusun koleksi buku dan beberapa rak buku gantung untuk menampilkan buku-buku yang menarik, sehingga membuat suasana membaca menjadi lebih menyenangkan bagi anak-anak.
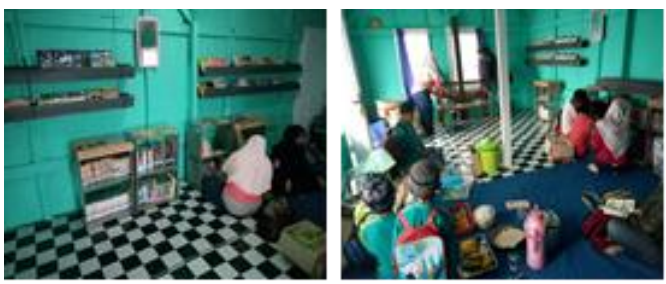

Gambar 11. Penataan Ruangan dengan Peralatan Penunjang

\section{Peresmian Taman Bacaan Sadulur}

Peresmian perpustakaan ini dilakukan pada hari Minggu tanggal 18 November 2018 dengan dihadiri oleh seluruh anggota P2M JTKE yang diketuai oleh Purwinda Iriani, M.Si. Saat peresmian dilakukan penyerahan perpustakaan "Taman Bacaan Sadulur" secara simbolis dengan memberikan buku kepada mitra yang diwakili oleh Ibu Dasimah selaku Ketua Kelompok Tani Ternak Sapi Sukatinggi 1 di Kampung Cisaroni. Adapun dalam proses peresmian ini juga disaksikan oleh Bapak Dwi Suhatanto, Ph.D. selaku pengawas yang melakukan monitoring kegiatan P2M Polban.
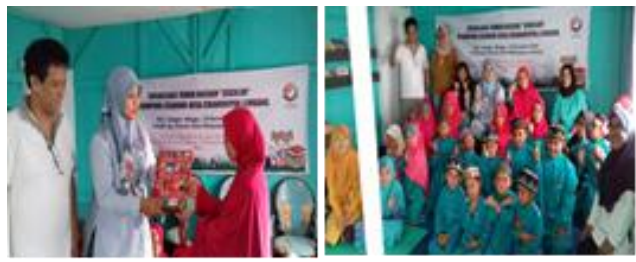

Gambar 12. Peresmian Perpustakaan Sadulur

Penamaan perpustakaan/taman bacaan ini diusulkan oleh tim pelaksana P2M JTKE sebagai identitas agar kelak dapat mempermudah identifikasi kepemilikan buku. Berdasarkan pertimbangan lokasi dan kearifan lokal dari mitra yang berada di wilayah Lembang dengan penduduk bersuku Sunda, maka tim P2M membuat nama SADULUR yang berarti "Sarumping Dugi Elmu Kaukur", yang berarti datang hingga ilmunya bertambah (terukur). Diharapkan dengan pemberian nama ini, taman bacaan menjadi sarana untuk meningkatkan kecerdasan anak-anak Desa Cisaroni melalui peningkatan minat baca. Desain logo taman disajikan pada Gambar 13 berikut ini.

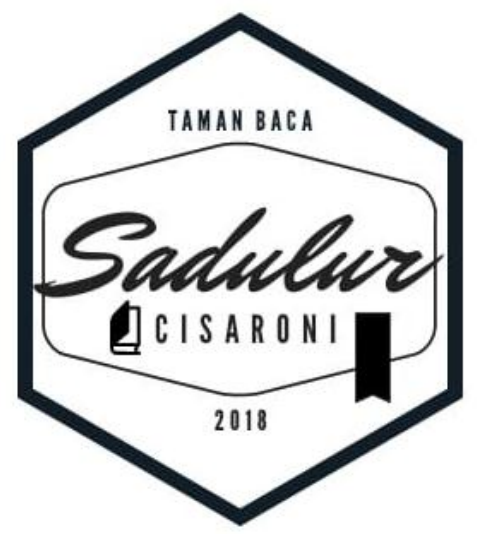

Gambar 13. Logo Taman Bacaan Sadulur

Arti dan Logo tersebut memiliki makna dan harapan dari tim P2M JTKE-Politeknik Negeri bandung, agar warga Mitra yang dapat memanfaatkan taman buku tersebut dapat memiliki pengalaman serta ilmu pengetahuan yang dapat menambah wawasannya. Dan harapan besarnya, anak-anak ini suatu saat akan mampu memberikan kontribusi untuk desanya melalui ilmu yang dimilikinya kelak.

\section{Pembinaan dan Sosialisasi.}

Tim pelaksana pengabdian masyarakat P2M JTKE mencoba membentuk tim kepengurusan yang terdiri dari warga masyarakat Cisaroni sendiri, dan memberikan pengenalan dan pengarahan dalam mengelola administrasi dan inventarisasi 
perpustakaan agar warga dapat melangsungkan perpustakaan secara mandiri. Sosialisasi mengenai taman bacaan sebenarnya telah dilakukan sejak saat survei awal. Dan sosialisasi lanjutan ini merupakan pengenalan kepada masyarakat tentang sistem perpustakaan yang akan diadaptasikan

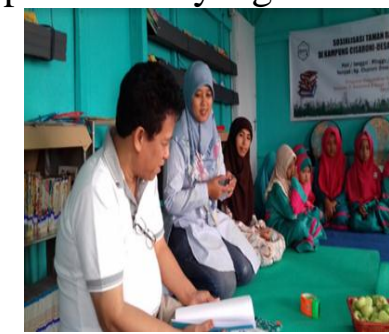

Gambar 14. Kegiatan Pembinaan, Sosialisasi dan Peresmian Taman Bacaan Sadulur

\section{Monitoring dan Evaluasi}

Tahap selanjutnya yaitu, proses pemantauan akan dilakukan oleh tim pengabdian masyarakat P2M JTKE. Proses ini akan dilakukan baik dengan kunjungan langsung ke perpustakaan, maupun tidak langsung dengan memanfaatkan perangkat komunikasi yang ada saat ini. Dalam tahap ini, akan diperhatikan ketaataan warga terhadap sistem administrasi pengelolaan perpustakaan yang telah diperkenalkan saat sosialisai dan peresmian. Selanjutnya, pada akhir masa pelaksanaan program pengabdian masyarakat akan dilakukan evaluasi awal untuk melihat seberapa besar kemampuan dari masyarakat untuk menjaga keberlangsungan dari perpustakaan beserta sistemnya.
(Gambar 14). Untuk memeriahkan suasana, pada saat sosialisasi dan peresmian Taman Bacaan Sadulur, juga diadakan acara mendongeng menggunakan buku koleksi, yaitu cerita nabi dan buku pembinaan karakter anak. 


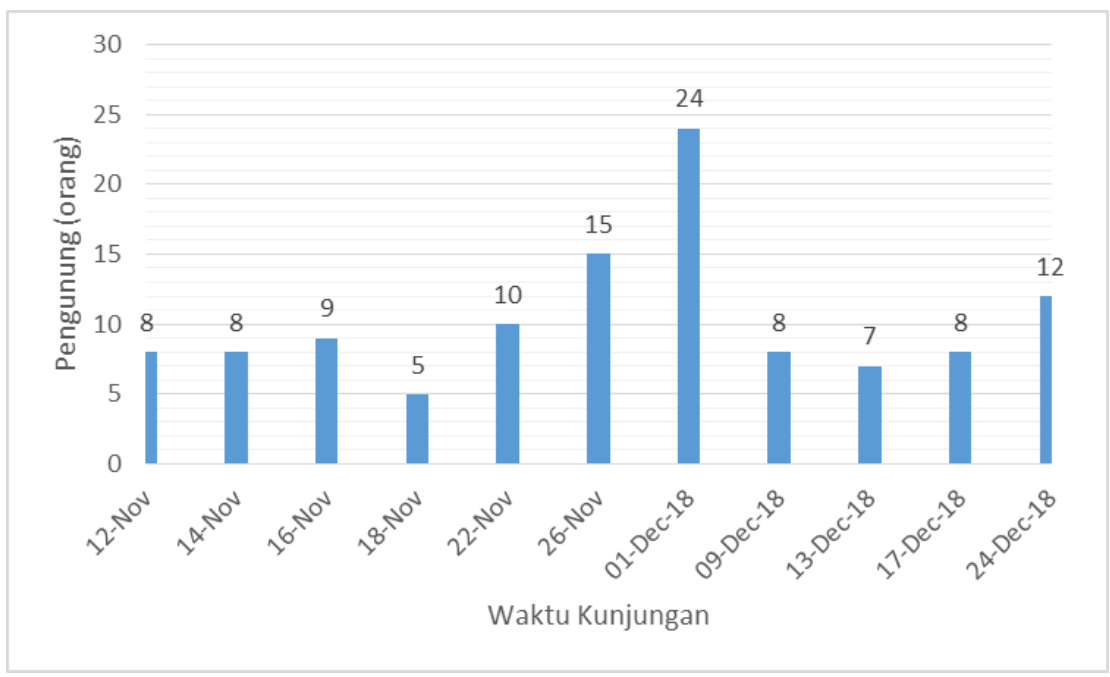

Gambar 15. Tabel Jumlah Kunjungan Taman Bacaan

Adapun evaluasi lanjutan, apabila warga dianggap telah cukup mampu untuk menjaga keberlangsungan fasilitas yang mereka miliki, dapat dilakukan peningkatan sarana, prasarana, dan segi pelayanan, melalui peminjaman buku koleksi. Berdasarkan hasil kunjungan taman bacaan yang telah berlangsung, respon warga dan pengunjung sangat positif, mengingat warga khususnya para anak-anak memiliki aktivitas bermanfaat lainnya melalui membaca buku.

\section{Rekomendasi dan Penyusunan Laporan Akhir}

Berdasarkan hasil monitoring dan evaluasi di atas, maka akan dapat dilihat hal- hal yang masih perlu dibenahi dan hal yang perlu dipertahankan dalam pengelolaan perpustakaan / Taman Bacaan Sadulur. Selain itu, apabila terdapat antusiasme dari pihak luar yang ingin memberikan bantuan dalam bentuk apapun guna mengembangkan kegiatan di taman baca ini, maka tim P2M JTKE akan dengan suka rela menjadi jembatan penghubung bagi pihak tersebut dan mitra. Adapun laporan hasil kegiatan pengabdian masyarakat bersama mitra, sebagian besar telah terangkum dalam laporan ini dan akan diserkan ke UPPM Polban dan juga kepada mitra.

\section{KESIMPULAN DAN SARAN}

Kegiatan pengabdian kepada masyarakat yang dilakukan antara Jurusan Teknik Konversi Energi dan mitra Kelompok Tani Ternak Sapi Sukatinggi 1 Desa Cisaroni - Lembang, menghasilkan beberapa output dan luaran, yakni :

1. Program pengabdian masyarakat telah dilaksanakan oleh tim P2M JTKE yang terdiri atas tiga orang dosen dari Jurusan Teknik Konversi Energi dan satu orang dosen dari Jurusan Teknik Referigasi dan Tata Udara Politeknik Negeri Bandung, di lingkungan warga RT 05 RW 08 Desa Cisaroni Kab. Lembang dengan Mitra yaitu Ketua Kelompok Tani Ternak Sapi Sukatinggi 1.

2. Kegiatan pengabdian masyarakat ini dilakukan dengan tahapan: kunjungan awal ke tempat Mitra dan calon lokasi penempatan taman baca (awal bulan Maret 2018), penentuan permasalahan spesifik, penyiapan ruang taman bacaan, pengadaan dan inventarisasi buku, penyiapan penunjang taman bacaan, peresmian taman bacaan sadulur (18 November 2018), monitoring dan evaluasi, pemberian rekomendasi dan penyusunan laporan.

3. Total buku yang diberikan yaitu sebanyak 411 buah buku yang terbagi ke 
dalam delapan jenis klasifikasi Dewey Decimal Classification, yaitu karya umum (000), agama (200), ilmu-ilmu social (300), ilmu-ilmu alam dan matematika (500), teknologi dan ilmu-ilmu terapan (600), kesenian, hiburan dan olahraga (700), kesusastraan (800), dan kategori geografi dan sejarah (900).

4. Dalam rangka pengelolaan, tim P2M JTKE telah melakukan beberapa kali sosialisasi kepada masyarakat Kp. Cisaroni untuk pengenalan taman bacaan dan sistem pengelolaan perpustakaan melalui pemberian panduan pengelolaan buku perpustakaan.

5. Selama proses persiapan hingga peresmian Taman Bacaan Sadulur ini, terlihat besarnya antusias baik dari anakanak sekolah, maupun para orang tua. Masyarakat Kp. Cisaroni sangat tanggap dalam membantu persiapan tempat dan bersikap terbuka terhadap adanya taman baca.

6. Hasil pemantauan selama dua bulan menunjukkan adanya kunjungan dan aktivitas membaca di Taman Bacaan Sadulur, dengan intensitas kunjungan 2-3 kali seminggu dan pengunjung di kisaran 7-24 orang setiap kunjungannya.

7. Tim P2M JTKE akan tetap melakukan pemantauan mengenai segi administrasi dan membuka peluang bagi pihak luar yang tertarik dalam membantu pengembangan Taman Bacaan Sadulur ini.

\section{UCAPAN TERIMA KASIH}

Unit Penelitian Pengabdian Masyarakat (UPPM) Politeknik Negeri Bandung melalui program penelitian Terapan Dana DIPA Polban tahun 2018.

\section{REFERENSI}

[1] Iriani, P., Suprianti, Y. \& Pudin, A., 2016. Pemanfaatan Limbah Ternak Sapi di Kelompok Tani Ternak Sukatinggi-1 Kampung CisaroniLembang, Bandung: Politeknik Negeri Bandung.

[2] Lasa, H., 2007. Manajemen Perpustakaan Sekolah. Yogyakarta: Pinus Book Publisher.

[3] Rahayu, W., Winoto, Y. \& Rohman, A. S., 2016. Kebiasaan Membaca Siswa Sekolah Dasar (Survei Aspek Kebiasaan Membaca Siswa SD Negeri 2 Pinggirsari di Desa Pinggirsari Kecamatan Arjasari Kabupaten Bandung). Jurnal Ilmu Perpustakaan, Informasi, dan Kearsipan Khizanah Al-Hikmah, 4(2), pp. 152-162.

[4] Saepudin, Encang. 2015. Tingkat Budaya membaca Masyarakat (Studi Kasus Pada Masyarakat di Kabupaten Bandung). Jurnal Kajian Informasi dan Perpustakaan. Vol.3/No2, hlm 271-282.

[5] Sumantri, M., 2002. Panduan Penyelenggaraan Perpustakaan Sekolah. Bandung: Remaja Rosdakarya.

[6] Yusuf, P. M., Suhendar \& Yaya, 2005. Pedoman Penyelenggaraan Perpustakaan Sekolah. Jakarta: Kencana. 